Jerzy Kaliszuk

Warszawa

\title{
Ponownie odnaleziony rękopis niemieckiego tekstu legendy o Barlaamie i Jozafacie
}

Jednym $z$ podstawowych elementów postępowania badawczego przy opracowywaniu rękopisu jest przebadanie jego historii. Ustalenie miejsca przepisania rękopisu, kręgu właścicieli i czytelników pozwala na lepsze zrozumienie mentalności i kultury duchowej czy religijnej danej epoki. Badanie proweniencji rękopisu opiera się na analizie bezpośredniej - odczytaniu not własnościowych, zamieszczanych zazwyczaj na wyklejkach lub pierwszych kartach książki i analizie pośredniej, przez gruntowne rozpatrzenie materiału pisarskiego, oprawy, pisma tekstu oraz not czytelników i wreszcie rozbiór tekstów zamieszczonych w kodeksie.

Niniejszy artykuł jest próbą odtworzenia skomplikowanych dziejów pewnego rękopisu, który $z$ powodu swojej zawartości uznawany był za jeden $z$ ważniejszych w historii literatury niemieckiej. Kodeks ten przechowywany jest obecnie w Bibliotece Narodowej (sygn. Akc. 8711). Jest to rękopis pergaminowy o wymiarach $26,5 \times 19,5 \mathrm{~cm}$, liczący 103 karty. Na podstawie cech paleograficznych można założyć, że powstał w pierw-szej połowie XIV w. Pierwotnie składał się $z$ dwóch części - część I, złożona głównie $z$ kwinternionów i kwaternionów, oznaczona kustoszami obejmowała karty 1-96 (składki I-XI), część II - to dwie nierówne składki (k. 97-103).

Podział ten odpowiada zawartości kodeksu. W części I, na k. 1r-96r znajduje się tekst niemiecki wierszowanej przeróbki legendy hagiograficznej o Barlaamie i Jozafacie, autorstwa Rudolfa von Ems. W części drugiej pomniejsze dziełka niemieckie $z$ XIII i XIV w.

Sama legenda o Barlaamie i Jozafacie jest chrześcijańską wersją dziejów Buddy ${ }^{1}$. Jozafat to Boddhisattva, co w sankrycie oznacza oświeconego, Barlaam

\footnotetext{
${ }^{1}$ Literatura na temat legendy jest dość obszerna, dlatego podaję tylko podstawowe opracowania, gdzie można znaleźć odniesienia do dalszej literatury: B. Altaner, A. Stuiber, Patrologia. Życie, pisma $i$ nauka Ojców Kościoła, Warszawa 1990, s. 677-679; J. Reczek, Barlaam i Jozafat, w: Encyklopedia katolicka, t. 2, Lublin 1995, kol. 34; Barlaam und Joasaph, w: Lexikon des Mittelalters, Bd. 1, kol. 14641469 (CD-Rom Ausgabe 2000). Tłumaczenie polskie, dokonane przez Sebastiana Piskorskiego w XVII w. wydał Jan Janów: Żywot Barlaama i Jozafata, Lwów 1935 (Zabytki Piśmiennictwa Polskiego, t. VI). Problematyka związana $z$ legendą o Barlaamie i Jozafacie omawiana będzie również w odrębnej publikacji.
} 
zaś to Bhagvan - ten termin równiė pochodzący $z$ sanskrytu, używany jest w hinduizmie na określenie przewodnika, boga czy pana. Opowieść ta przeszła $z$ Indii do Persji, gdzie dokonano najstarszej redakcji pisanej w dialekcie pahlavi. Następnie dotarła do Syrii i kręgu arabskiego oraz do Gruzji. W XI w. wersja gruzińska legendy została przełożona na język grecki, tradycja i niektórzy badacze przypisywali autorstwo tłumaczenia św. Janowi Damasceńskiemu (ok. 650-przed 754) ${ }^{2}$. W arabskim tłumaczeniu legendy Jozafat występował jako Budasaf, następnie Jodasaf, by w wersji greckiej przyjąć formę Joasaph. Tekst grecki był następnie podstawą tłumaczenia łacińskiego, znanego w całej Europie. Popularność tekstu była duża, treści zaś tam zawarte tak atrakcyjne, że dokonywano tłumaczeń na języki rodzime. W ciągu dwóch stuleci od początków XIII w. do początków wieku XVI przetłumaczono legendę na języki: niemiecki, francuski, włoski angielski, norweski i islandzki. Od XV w. znanych jest równiė̇ kilka edycji drukowanych, dokonywanych w Spirze (1472/73), Strassburgu (1474), Antwerpii i Bazylei (druga połowa XVI w.) ${ }^{3}$.

Popularność tekstu legendy znalazła także odbicie w hagiografii średniowiecznej. Barlaam i Jozafat byli uważani za świętych, sama zaś historia, w skróconej formie, znalazła się między innymi w Złotej legendzie Jakuba de Voragine. Formalnie zostali oni kanonizowani w XVI w., ich święto zaś przypada na dzień 27 listopada.

Treść legendy przedstawia się następująco. Przy okazji narodzin syna Jozafata, pogański król indyjski Awenir (Abener) uzyskał od magów przepowiednię, że w przyszłości syn zwróci się wbrew woli ojca ku chrześcijaństwu. Aby zapobiec spełnieniu proroctwa, Awenir polecił odgrodzić syna od świata zewnętrznego i rozpoczął długotrwałe prześladowanie chrześcijan. Jozafat, jako młodzieniec, potajemnie opuścił pałac by poznawać świat. Na swojej drodze napotkał różne uosobienia cierpień: trędowatego, niewidomego i wreszcie starca. Spotkania te okazały się dla niego przełomem, Jozafat zaczął zastanawiać się nad sensem życia i tym, co się dzieje $z$ człowiekiem po śmierci. W tak niespokojnym stanie ducha spotkał na wyspie Sennaar chrześcijańskiego pustelnika imieniem Barlaam, który pouczył go w wierze i nauce chrześcijańskiej. Po nawróceniu Jozafat postanowił rozkrzewić wiarę chrześcijańską. Awenir, widząc że wszystkie jego starania spełzły na niczym, zdecydował się oddać synowi połowę królestwa. Ostatecznie sam też się nawrócił i abdykował, aby spędzić resztę życia w pustelni. Jozafat już jako władca wypełnił zalecenia ojca i Barlaama, dotyczące chrystianizacji poddanych, a następnie po śmierci ojca sam abdykował i też został pustelnikiem.

W przypadku legendy o Barlaamie i Jozafacie mamy więc do czynienia $z$ tekstem, który, pomimo swojego pochodzenia, $z$ jednej strony głosił przewagę

\footnotetext{
${ }^{2}$ Zob. F. Dolger, Der grechische Barlaam-Roman ein Werk des H. Johannes von Damaskos, Ettal 1953 (Studia Patristica et Bizantina, H. 1); P. Devos, Les origines du „Barlaam et Joasaph” grec, „Analecta Bollandiana”, 75:1957, s. 83-104.

${ }^{3}$ Dla inkunabułów zob. Gesamtkatalog der Wiegendrucke, nr 3396-3397 (tekst łaciński), nr 33983399 (tekst niemiecki).
} 
chrześcijaństwa nad innymi religiami, $z$ drugiej zaś zawierał w swojej treści zalecenie i ideał pogardy wobec świata (contemptus mundi).

Tekst legendy opracowany przez Rudolfa von Ems, obok tzw. Laubacher Barlaam autorstwa biskupa Ottona $z$ Freising, jest drugą niemiecką przeróbką opowieści o Barlaamie i Jozafacie.

Niewiele wiadomo o autorze tej wersji legendy o Barlaamie ${ }^{4}$. Rudolf von Ems urodził się prawdopodobnie około 1200 r. w Hohenems (Vorarlberg, Austria). Pozostawał jako ministeriał w służbie rodu von Montfort. Swoje teksty tworzył w latach 1220-1250 r. Anonimowy kontynuator Kroniki Świata (Weltchronik) Rudolfa von Ems podał, że zmarł on w Italii, gdzie prawdopodobnie przebywał u boku króla Konrada IV w 1254 r. ${ }^{5}$ Obecnie Rudolf uważany jest za jednego $z$ najbardziej wykształconych poetów swojej epoki. Nie zachowały się wszystkie dzieła jego autorstwa. Z prac jego należy wymienić Der guote Gerhart (napisane między 1220-1225), Barlaam und Josaphat (1225-1230) oraz Wilhelm von Orleans - epos dworski, oparty na francuskim tekście, opowieść o miłości dziecięcej między Wilhelmem a Amelią. Inne dzieło znane tylko w fragmentach, to prawdopodobnie niedokończona powieść dworsko-rycerska o Aleksandrze Wielkim (Alexanderroman), którą Rudolf zaczął pisać około 1240 r., nawiązując do wcześniejszych tekstów, takich jak Historia de Praeliis i Historiae Alexandri Magni Kurcjusza Rufusa. Rudolf nie zdążył dokończyć swojej Kroniki Świata (Weltchronik) (ok. 1250 r.), uważanej za pierwszą niemieckojęzyczną kronikę uniwersalną.

Interesujący nas tekst legendy o Barlaamie i Jozafacie był już obiektem dociekań niemieckich badaczy literatury. W początkach XIX w., dokładniej w 1818 r., germanista królewiecki Friedrich Karl Köpke wydał tekst legendy, przypisując jej autorstwo Rudolfowi von Montfort ${ }^{6}$. Za podstawę edycji posłużyły mu dwa czternastowieczne rękopisy znajdujące się w Bibliotece Uniwersyteckiej w Królewcu. Dwadzieścia pięć lat później, w 1843 r. ukazała się edycja dokonana przez Franza Pfeiffera, późniejszego bibliotekarza w Stuttgar-cie i profesora literatury niemieckiej w uniwersytecie wiedeńskim (1815-1868) ${ }^{7}$. W nocie edytorskiej Pfeiffer wyliczył dwanaście rękopisów i trzy fragmenty pochodzące $z$ okresu od XIII do XIV w. Wydanie to, jakkolwiek nie zostały uwzględnione w nim wszystkie rękopisy, uznane zostało za najlepsze i obowią-zujące do czasów obecnych ${ }^{8}$.

\footnotetext{
${ }^{4}$ Zob. W. Walliczek, Rudolf von Ems, w: Verfasserlexikon der deutschen Literatur des Mittelalters (dalej VL), 2 Aufl., Bd. 8, Berlin-New York 1992, kol. 322-345.

${ }^{5}$ Weltchronik.

${ }^{6}$ Barlaam und Josaphat von Rudolf von Montfort, hrsg. von Fr.K. Köpke, Königsberg 1818 (2 wydanie - Leipzig 1838).

${ }^{7}$ Barlaam und Josaphat von Rudolf von Ems, hrsg. von F. Pfeiffer, Leipzig 1843 (Dichtungen des deutschen Mittelalters, Bd. 3) - przedruk ze wstępem Heinza Ruppa, Berlin 1965. O osobie wydawcy zob. J. Strobl, Pfeiffer Franz, w: Allgemeine Deutsche Biographie, Bd. 25, Leipzig 1887, kol. 635-639.

${ }^{8}$ Zob. S. Prillwitz, Überlieferungsstudie zum Barlaam und Josaphat des Rudolf von Ems. Eine textkritisch-stemmatologische Untersuchung, Kopenhagen 1975.
} 
Obok legendy o Barlaamie i Jozafacie w rękopisie Biblioteki Narodowej znajdują się jeszcze inne teksty, które składają się na część II kodeksu. Ostatnia składka zawiera więc niemieckie kazanie na temat św. Jana Chrzciciela prawdopodobnie autorstwa dominikanina Hugona $z$ Konstancji (k. 97r-101v). Hugo był w latach 1279-1288 lektorem w klasztorze dominikańskim w Konstancji, niewykluczone, że można go utożsamić ze zmarłym w 1303 lub 1304 r. prowincjałem Hugonem $z$ Zurichu'. Ostatnie teksty w rękopisie to anonimowa alegoria miłości w formie opowieści o łowach (Jagdallegorie) (k. 102r-103v) oraz krótka modlitwa ${ }^{10}$.

Cały kodeks pisany jest teksturą gotycką trzech rąk. Ręka A przepisała k. 1r96r, ręka B - pismo mniejsze, z mniejszą interlinią (k. 97r-101v), ręka C - k. 102r103v. W rękopisie występują nieliczne zdobienia wykonane czerwoną farbą, głównie w części I, w części II kolorem tym wykonano tylko inicjał na k. 97r. Zdobienia te obejmują inicjały oraz przekreślone pierwsze litery poszczególnych wierszy. Dodatkowo na k. 4r kopista wypełnił pola w dwóch inicjałach D przedstawieniami ludzkich twarzy $z$ profilu, wykonanymi piórkiem i czarnym atramentem. Inny element estetyczny to zachowane tzw. „cery” pergaminu - wypełnienia nićmi w dwóch kolorach: zieloną i czerwoną znajdujące się na kartach 12, 69, 76, 94.

Rękopis nie posiada praktycznie żadnych not marginalnych. Tylko na dolnym marginesie k. 103r umieszczono w XV w. notkę: „wolvf der frauen wellen phlegen des, oraz poniżej tą samą ręką: „wol”. W XIX w., nieznany badacz (Köpke?) napisał ołówkiem na marginesie k. 11v: „Hier fehlen zwei Blaetter”, na k. 30r zaś: „Die ir Kunige lieggen Cod. Berolin.”.

Rękopis zaopatrzony jest w oprawę średniowieczną, czyli zrobioną z desek obciągniętych skórą. Co ciekawe, $z$ przetarć wierzchniej skóry wyziera warstwa starsza, skóra czerwona $z$ wyciskanym ornamentem linearnym. Skóra zewnętrzna jest jasna, niebarwiona i niezdobiona, zamszowa. Na oprawie nie było żadnych guzów, natomiast zachowały się mocowania dwóch klamer na przedniej oprawie i ślady po bolcach znajdujących się na środku tylnej oprawy. Grzbiet jest obecnie w złym stanie, częściowo oderwany od bloku książki, naklejono na nim dwie kartki, $z$ których zachowała się tylko jedna. Na tylnej okładce znajduje się naklejona kartka, na której pieczęcią tuszową odbity został, aczkolwiek bardzo niewyraźnie, ekslibris rodziny Brzozowskich. Ten sam znak własnościowy pojawia się również na k. 17r oraz, i to dwukrotnie, na wyklejce przedniej.

Jak wynikałoby z powyższego opisu kwestia proweniencji, przynajmniej na przełomie XIX i XX w., wydaje się nie budzić wątpliwości. Jednak przeświadczenie to jest pozorne. W 1967 r. rękopis został zakupiony przez Bibliotekę Narodową od osoby prywatnej. Pieczątki tuszowe $z$ ekslibrisem stanowią więc wła-

${ }^{9}$ D. Ladisch-Grube, K. Ruh, Hugo von Konstanz, w: VL, Bd. 2, kol. 232-233; T. Kaeppeli, Scriptores Ordinis Praedicatorum Medii Aevi, t. II, Roma 1975, s. 255 (inny incipit).

${ }^{10}$ W. Blank, Jagdallegorie, w: VL, Bd. 2, kol. 468-469. 
Ponownie odnaleziony rękopis niemieckiego tekstu legendy o Barlaamie i Jozafacie

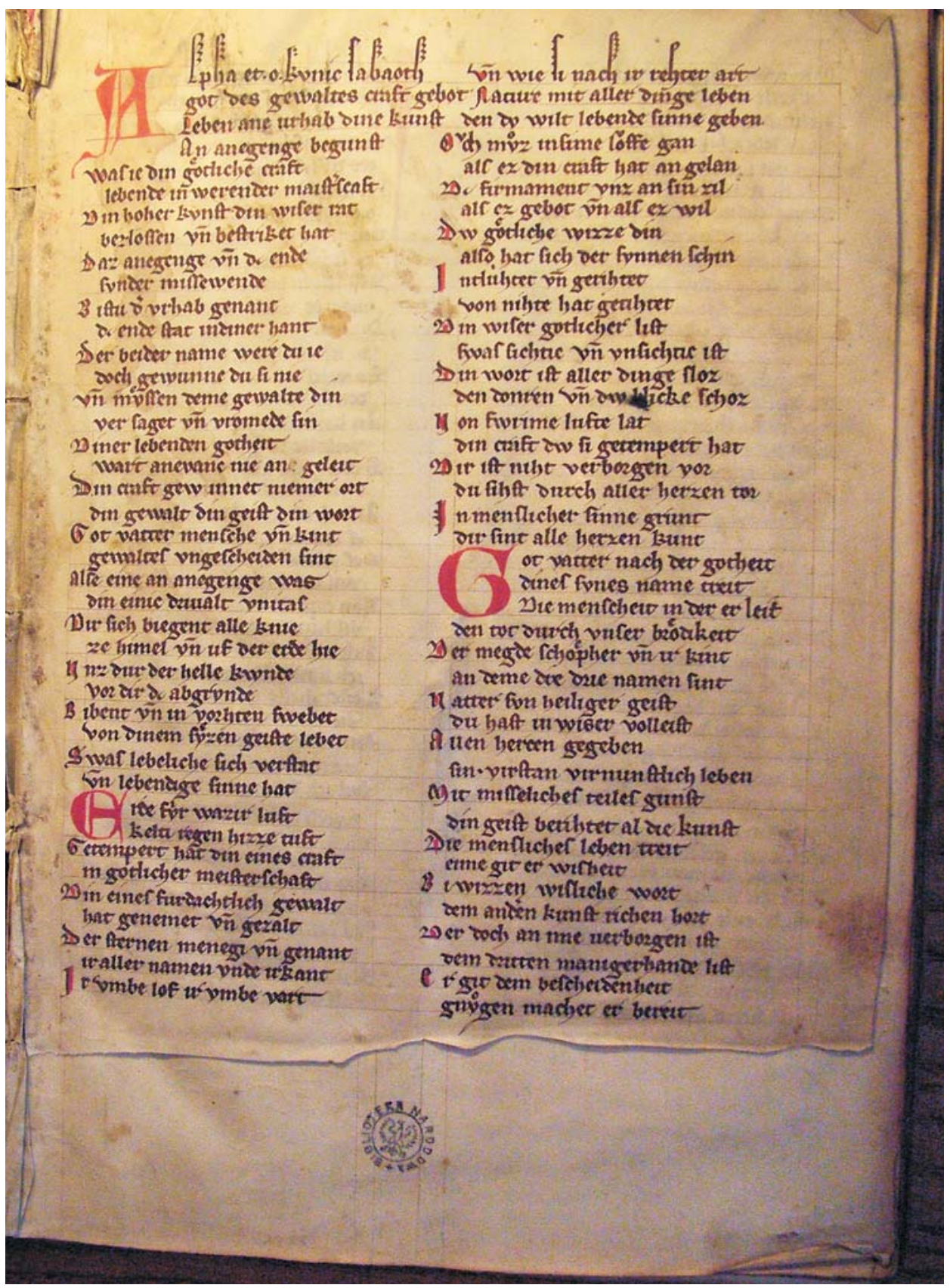

BN akc. 8711, k. 1r, Rudolf von Ems, Legenda o Barlaamie i Jozafacie - początek tekstu, karta Z uciętym dolnym marginesem. 


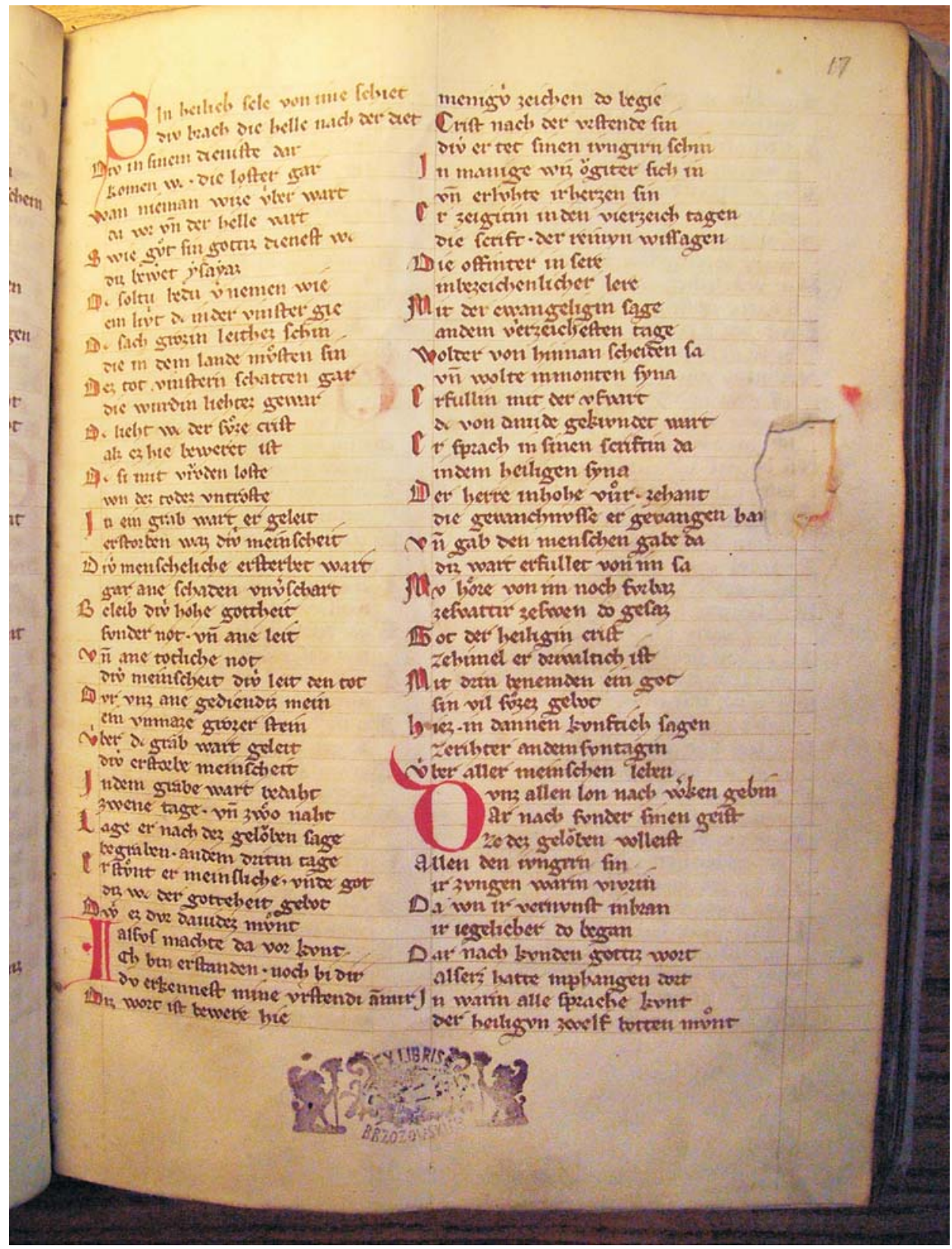

BN akc. 8711, k. 17r, Rudolf von Ems, Legenda o Barlaamie i Jozafacie - pieczątka tuszowa na marginesie dolnym $z$ ekslibrisem. 
ściwy punkt wyjścia badania wcześniejszych losów kodeksu. Pojawia się jednak pierwszy problem - poszukiwania w zbiorach ekslibrisów polskich przechowywanych w Bibliotece Narodowej oraz Zakładzie Narodowym im. Ossolińskich przyniosły rezultat negatywny ${ }^{11}$. Co więcej, mało prawdopodobne wydaje się, że jakikolwiek kolekcjoner zamieściłby swój ekslibris, odbijając go pieczątką tuszową $\mathrm{w}$ trzech miejscach na kartach pergaminowych średniowiecznego rękopisu! Kwestia przynależności kodeksu do konkretnego księgozbioru pozostałaby więc prawdopodobnie bez rozwiązania, gdyby nie przypadkowe sięgnięcie do katalogów średniowiecznych rękopisów niemieckich. Jednym $z$ nich był katalog średniowiecznych rękopisów niemieckojęzycznych $Z$ dawnej biblioteki uniwersyteckiej w Królewcu ${ }^{12}$. Katalog ten, będący rekonstrukcją części zasobu ksiąg przechowywanych w Królewcu przed 1945 r., obejmuje opisy dokonane przez tamtejszego bibliotekarza Ludwiga Deneckego w drugiej połowie lat trzydziestych XX w. Działania wojenne przeszkodziły zarówno publikacji tego katalogu, jak tė̇ przyczyniły się w konsekwencji do rozproszenia samego księgozbioru. W katalogu tym znajduje się opis kodeksu całkowicie zbieżny pod względem opisu kodykologicznego i zawartości z rękopisem Biblioteki Narodowej ${ }^{13}$. Co więcej, jest tam dodatkowa informacja o powojennym miejscu przechowywania rękopisu. Miał on się znajdować w bibliotece uniwersyteckiej w Toruniu, pod sygn. Rps 28/III, jednak od 1960 r. został uznany za zaginiony. Oznacza to więc, że kodeks ten, zaginiony w 1960 r., po siedmiu latach został zakupiony przez Bibliotekę Narodową. W czasie owych siedmiu lat (1960-1967) dokonano zabiegów mających na celu całkowitą eliminację wszelkich znaków proweniencyjnych wskazujących na Królewiec i Toruń. Wycięto bowiem te fragmenty kart pergaminowych, w których znajdować się mogły pieczątki bibliotek: na karcie początkowej i końcowej $(\mathrm{k} .1,103)$ wycięte zostały dolne marginesy. Co więcej, dla odwrócenia uwagi posunięto się do fałszerstwa, przez dodanie czterech znaków proweniencyjnych w postaci niewyraźnych odcisków pieczętnych, umieszczając je zarówno na okładce, jak i wewnątrz kodeksu.

Po tych konstatacjach, które zawiodły do bibliotek uniwersyteckich w Królewcu i w Toruniu, warto zastanowić się nad wcześniejszymi losami kodeksu. Istotna jest informacja o tym, że w pierwszej połowie XVI w. kodeks ten znajdował się w Tapiawie (niem. Tapiau, obecnie Gvardijsk w obwodzie kaliningradzkim). W Tapiawie znajdowała się centralna biblioteka i archiwum zakonu krzyżackiego, a jego zasób stanowiła prawdopodobnie biblioteka wielkiego mis-

\footnotetext{
${ }^{11}$ Dziękuję za informację panu Arkadiuszowi Dobrzynieckiemu z Biblioteki Zakładu Naukowego im. Ossolińskich we Wrocławiu.

${ }^{12}$ Katalog der mittelalterlichen deutschsprachigen Handschriften der ehemaligen Staats- und Universitätsbibliothek Königsberg. Nebst Beschreibungen der mittelalterlichen deutschsprachigen Fragmente des ehemaligen Staatsarchivs Königsberg, auf der Grundlage der Vorarbeiten Ludwig Deneckes erarbeitet von Ralf G. Päsler, hrsg. von Uwe Meves, München 2000 (Schriften des Bundesinstituts für ostdeutsche Kultur und Geschichte, Bd. 15).

${ }^{13}$ Tamże, nr 898, s. 91-93.
} 
trza z Malborka oraz księgozbiory innych zamków, włączone do niej po $1466 \mathrm{r}$. i po sekularyzacji zakonu. W 1541 i 1543 r. przeszło 300 rękopisów przewieziono do biblioteki książęcej (Kammerbibliothek) w Królewcu. Następnie trafiły one wraz $z$ całym księgozbiorem do biblioteki Uniwersytetu w Królewcu (Albertyny) ${ }^{14}$. Rękopisy te, podobnie jak inne książki Nowej Biblioteki, były przeoprawiane w drugiej połowie lat pięćdziesiątych XVI w. w białą skórę świńską oraz zaopatrzone w drzeworytowy ekslibris naklejany na odwrocie okładki przedniej ${ }^{15}$. Wyjaśniałoby to podwójne obciąnnięcie skórą desek $z$ oprawy rękopisu Biblioteki Narodowej.

Podążając dalej tym tropem, można przypuszczać, że książka ta mogła znajdować się w którymś $z$ księgozbiorów zakonnych. Podstawowym źródłem są tu inwentarze majątkowe poszczególnych domów zakonu krzyżackiego, zawierające również spisy ksiąg ${ }^{16}$. Wśród „ksiąg niemieckich” wymienionych w spisach odnaleźć można cztery rękopisy $z$ tekstem legendy o Barlaamie i Jozafacie. W inwentarzu zamku w Malborku z 1394 i 1398 r. wymienione zostały dwa egzemplarze ${ }^{17}$. W pierwszym kodeksie legenda znajdowała się razem $z$ niemieckim opracowaniem eposu rycerskiego poety niemieckiego $z$ pierwszej połowy XIII w. określanego jako Stricker (Powroźnik) ${ }^{18}$, w drugim została zamieszczona $z$ pieśnią o Rolandzie. Warto zauważyć, że w inwentarzach odnotowywano zazwyczaj pierwszy tekst znajdujący się w rękopisie, dlatego te $\dot{z}$ mało prawdopodobne wydaje się, że któryś $z$ rękopisów malborskich mógłby być tożsamy $z$ kodeksem $z$ Biblioteki Narodowej. Bardziej prawdopodobna wydaje się identyfikacja $z$ którymś $z$ dwóch innych, wymienionych w spisach rękopisów, które znajdowały się w księgozbiorach komturii w Ostródzie (inwentarz z 1437) i Elblągu $(1440)^{19}$. Nie wyczerpuje to liczby kopii rękopiśmiennych niemieckiej legendy o Barlaamie i Jozafacie. Między innymi rękopisami z Tapiawy znajdował się również ten określony w inwentarzu archiwum jako „Reimen auff daß buch Job vnd andere patriarch[en] auf pergamein geschriben”. W rzeczywistości kodeks ten $z$ pierwszej połowy XV w., zawiera parafrazę księgi Hioba, po czym następuje interesujący nas tekst legendy o Barlaamie i Jozafacie Rudolfa von

${ }^{14}$ Zob. np. J. Tondel, Biblioteka zamkowa (1529-1568) księcia Albrechta pruskiego w Królewcu, Toruń 1992, passim.

${ }^{15}$ Tamże, s. 104-106.

${ }^{16}$ Wydania: Das Grosse Ämterbuch des Deutschen Ordens, hrsg. von W. Ziesemer, Danzig 1921 (dalej GAB), Das Marienburger Ämterbuch, hrsg. von W. Ziesemer, Danzig 1916 (dalej MAB). Podstawową pracą na temat księgozbiorów zakonu krzyżackiego w Prusach, jak też źródeł do ich poznania jest artykuł E. Potkowskiego, Duchowość krzyżaków a lektura. Księgozbiory zakonu krzyżackiego w Prusach, w: Bibliologia dyscyplina integrująca. Studia ofiarowane Barbarze Bieńkowskiej, tom specjalny „Z badań nad polskimi księgozbiorami historycznymi”, Warszawa 1993, s. 89-110.

${ }^{17}$ MAB, s. 124 - item Barlaam unde der Stricker in eyme buche, 125 - Item Job Barlaam und Ruland in eyme buche [...] Barlaam und Strycker in eyme buche.

${ }^{18}$ O Strickerze zob. W. Röcke, Der Stricker, w: Lexikon des Mittelalters, Bd. 8, Cd-Rom Ausgabe 2000, kol. 242-244, K.-E. Geith, E. Ukena-Best, H.-J. Ziegeler, Der Stricker, w: VL, Bd. 9, Berlin 1995, kol. 417-449.

${ }^{19}$ GAB, s. 93 - item Barlaam, 332 - item 1 buch genant Barlaam. 
Ems, a za nim parafraza księgi Daniela, pochwała Marii (Marienlob aus dem Passional) i w końcu niemiecki tekst Credo ${ }^{20}$.

Ostatnia kwestia to funkcjonowanie tekstu legendy o Barlaamie i Jozafacie w kulturze zakonu krzyżackiego. Jak słusznie zauważył Edward Potkowski, „księgi niemieckie”, głośno czytane w czasie wspólnych posiłków zakonników (,dutsche bucher czum tischlesen”²1), cieszyły się największym zainteresowaniem słuchaczy - braci rycerzy, którzy wcale nie musieli znać łaciny, by je rozumieć. Co więcej, $z$ badań tego autora wynika, że w grupie tekstów niemieckich dominowała literatura religijno-dydaktyczna, choć występowała również historiografia oraz poezja rycersko-dworska ${ }^{22}$. Legenda o Barlaamie i Jozafacie, będąca pochwałą życia monastycznego i traktująca o zwycięstwie chrześcijaństwa nad innymi religiami, była idealną lekturą budującą dla rycerzy zakonnych. Umacniała ich w przekonaniu o słuszności idei szerzenia prawdziwej wiary na rubieżach chrześcijańskiej Europy. Była wszak tekstem, który zyskał popularność w konkretnym momencie historycznym - czasach krucjat prowadzonych przeciw muzułmanom i poganom. Stąd wynikała jej popularność w środowisku rycerzy w habitach.

\section{Zawartość rękopisu BN Akc. 8711}

Niem., 1 poł. XIV w., perg., 26,5x19,5 cm, k. 103.

\section{1. k. 1r-96r [Rudolf von Ems, Barlaam und Josaphat]}

Alpha et o kunic Sabaoth got, des gewaltes craft gebot ... $><\ldots$ dez helfe unz $\mathrm{d} z$ lebinde brot. Alfa et o kunic. Sabaot. Amen. Finito libro sit laus et gloria Christo.

Brak 2 k. między k. 11 a 12 (notka ołówkiem w j. niem. na k. 11v: Hier fehlen zwei Blaetter) $=$ kol. 46 w. $30-$ kol. 54 w. 32 w edycji Pfeiffera.

Ed. Barlaam und Josaphat von Rudolf von Ems, hrsg. von F. Pfeiffer, Leipzig 1843 (Dichtungen des deutschen Mittelalters, Bd. 3).

Lit. S. Prillwitz, Überliefeungsstudie zum Barlaam und Josaphat des Rudolf von Ems. Eine textkritisch-stemmatologische Untersuchung, Kopenhagen 1975.

k. $96 \mathrm{v}$ niezapisana

\footnotetext{
${ }^{20}$ Katalog der mittelalterlichen deutschsprachigen Handschriften ..., nr 890b, s. 80-82. Obecnie w Bibliotece Uniwersyteckiej w Toruniu, sygn. Rps. 40/IV.

${ }^{21}$ Np. GAB. s. 600, 602.

${ }^{22}$ E. Potkowski, Duchowość krzyżaków a lektura..., s. 94.
} 
2. k. 97r-101v [Hugo von Konstanz, Predigt über Johannes den Täufer] Wir lesen in dem ewangelio daz sant Lucas sprichet von dem grozem herren sant Johannes Baptist daz in unser herre lopte an fünf dingen ...> $<$...Ecce agnus dei. Sehent daz ist daz lamp gottes daz aller der welte sunde vf im treit.

Ed. A. Holder, Zwei Predigten des Lesemeisters Hugo von Constanz, „Zeitschrift für deutsche Philologie" 9 (1878), s. 29-43.

\section{3. k. 102r-103v Jagdallegorie}

Het ich ze iagende sinne guot / so wolt ich mit wisem muot ... $><\ldots$ Amen sprechent alle / den dise rede geualle.

Ed. K. Stejskal, Königsberger Jagdallegorie, „Zeitschrift für deutsche Altertum und deutsche Literatur” 24 (1880), s. 254-268.

\section{4. k. 103v Gebet}

O Herre Got Vater erbarme dich genediklichen über mich, la mich von dir nicht scheiden. Amen. [poniżej:] Gaudeamus omnis in domino Iesu Christo.

\section{Opis}

1. Składki : I (3+4) (jedna k. wycięta), k. 1-7; II (4+4), k. 8-15 (brak środkowego bifolium); III (5+5), k. 16-25; IV (5+5), k. 26-35; V (5+5), k. 36-45; VI (4+4), k. 46-53; VII (4+4), k. 54-61; VIII (4+4), k. 62-69; IX (4+4), k. 70-77; X (4+4), k. 78-85; XI (5+5), k. 86-95; XII (1+0), k. 96; XIII (3+1), k. 97-101, XIV (2+2), k. 101-103 (jedna k. służy jako wyklejka).

Kustosze: k. 7v - I, 8r - II, 16r - IIIus, 26r - IIIIus, 36r - Vus, k. 53v - VI, 61v - VII, szczątkowy na k. 69v- VIII, k. 77v - IX, k. 85v - X, k. 95v-XI.

Pierwotnie kodeks składał się z dwóch części: cz. I - k. 1-96 (składki I-XI oznaczone kustoszami oraz ostatnia XII); cz. II - k. 97-103 (składki XIII-XIV).

2. Pergamin gruby, cery wykonane czerwoną i zieloną nicią, na k. 12, 69, 76, 94.

3. Pismo i zdobienia

Pismo trzech rąk:

A. k. 1-96r minuskuła gotycka textualis. Pierwszy wiersz kolumny - laski wyciągnięte do góry ze zdobieniami (wici);

B. k. 97r-101v minuskuła gotycka textualis. Pismo mniejsze, ściśnięte z mniejszą interlinią;

C. k. 102r-103v minuskuła gotycka textualis. Pismo pośrednie między A i B. Zdobienia tylko w części I (do k. 96r) W części II tylko 1 inicjał rubro na k. 97 r. 
Zdobienia wyłącznie rubro - inicjały, przekreślone pierwsze litery wiersza. Kopista wpisywał litery do malowania na marginesie, a nie w polu inicjału. Wycięty inicjał na k. $17 \mathrm{v}$. Na k. 4r wypełnione pola w dwóch inicjałach D - piórkiem czarnym atramentem przedstawienia twarzy ludzkich $z$ profilu.

\section{Noty i glosy}

Ołówkiem w j. niem. XIX w. na k. 11v: „Hier fehlen zwei Blaetter”; k. 30r: „Die ir Kunige lieggen Cod. Berolin.” autorstwa być może wydawcy; k. 103r na dolnym marginesie ręką XV w.: „wolvf der frauen wellen phlegen des.” i poniżej tą samą ręką: „wol”.

\section{Oprawa}

Deski podwójnie obciągnięte skórą: warstwa dolna - skóra czerwona $z$ wyciskanym ornamentem linearnym, warstwa wierzchnia - jasna skóra niebarwiona i niezdobiona, zamszowa. Brak guzów, zachowane mocowania do 2 klamer na przedniej oprawie - ślady po bolcach na środku tylnej oprawy. Grzbiet w części oderwany, naklejone pierwotnie 2 kartki $z$ których zachowała się tylko jedna. Na tylnej okładce naklejona kartka na której pieczęcią tuszową odbity ekslibris Brzozowskich. Na wyklejce przedniej dwie pieczątki tuszowe $z$ ekslibrisem Brzozowskich

6. Proweniencja

Tapiau

Königsberg - Staats- und Universitätsbibliothek

Toruń - Biblioteka Uniwersytecka, sygn. 28/III - do 1960 r.

Biblioteka Narodowa - od 1967 r.

7. Stan zachowania:

Przednia oprawa luźna, trzyma się tylko na skórze.

Ubytki na rogach.

Wycięte dolne części kart 1 (pierwsza) i 103 (ostatnia) - prawdopodobnie znajdowała się tam pieczątka tuszowa Biblioteki UMK w Toruniu. 